\title{
Academic freedom and the commercialisation of universities: a critical ethical analysis
}

\author{
Kathleen Lynch*, Mariya Ivancheva \\ Equality Studies Centre, School of Social Justice, University College Dublin, Belfield Dublin 4, Ireland
}

\begin{abstract}
This paper explores the cultural and organisational dimensions of academic life that lay the foundations for academic freedom. We briefly review the relationship between university autonomy and academic freedom, the relationship between ethics and freedom and the impact of increased commercialisation on scholarly independence, particularly how the increasing casualization of employment limits the freedom of academics to teach critically and publish freely. We examine the geopolitics of knowledge and how the hegemony of Western thinking frames dominant epistemologies and imposes constraints on academic freedom. We also explore the ways in which Cartesian rationalism underpins contemporary understanding of what constitutes valid knowledge, and how this can and does act as a constraint in what we come to know and study, not least in terms of values but also in terms of how caring (affective) relations impact research and teaching. Our paper highlights the silenced doxa in the organisation of the academy, including the impact of care-lessness on women and primary care givers in particular. We examine the social class biases in how higher education is organised, and how class exclusions are themselves constraints on being an academic or a student in a university. Finally, the paper illustrates the importance of distinguishing between the institutional autonomy of the university, the personal and professional freedoms of individual academics, and each of these from subject autonomy, namely the freedom of scholars to create and maintain new disciplinary fields, especially fields of scholarship that are critical and challenging of prevailing academic orthodoxies.
\end{abstract}

KEY WORDS: Academic freedom · Autonomy · Care-lessness • Tenure · Casualization · Neoliberalism

\section{UNIVERSITIES AND HIGHER EDUCATION}

The expansion of higher education over the last 30 years has not only radically altered the intake into higher education, but it has also changed the character of higher education itself. Greatly increased participation rates have been accompanied by institutional stratification, both intra- and internationally, not only between universities and other degree- and diploma-awarding institutions, but also between universities themselves. Colleges and universities are differentiated in terms of both their educational and research status, differentiations that are exacerbated with the growth of global ranking systems (Hazel-

${ }^{*}$ Corresponding author: kathleen.lynch@ucd.ie korn 2011, Cantwell 2013, Lynch 2014). While the differentiations between universities, and between these and other colleges of higher education, are socially significant $\underline{\underline{1}}$, the issue of academic freedom arises in all cases. It is not the exclusive concern of those working in universities or elite institutions. Wherever academic scholarship is being pursued, the issue of academic freedom arises, albeit in contextspecific forms.

\footnotetext{
15ome higher educational institutions have higher status than universities, notably the Grandes écoles in France, and some have lower status, such as Community Colleges in the USA. 


\section{UNIVERSITIES AND AUTONOMY ${ }^{2}$}

Universities are recognised as places for advanced scholarly learning, research and conferring degrees; however, there is less agreement as to what constitutes the primary purpose of universities. Those who subscribe to Newman's or Humboldt's idea of a university assume they are fundamentally places for nonvocational higher education and research, and equally places where people exercise freedom to teach and learn without interference ${ }^{3}$. Yet, early university-style institutions such as Abbasid's House of Wisdom in Baghdad and the Imperial Academy (Taixue) in China had a strong (though not exclusive) focus on religious and civil service education, respectively (Stothoff Weber 1946, Badeau \& Hayes 1976, Kaviani et al. 2012). Many European universities had their origins in cathedral schools and were controlled by religious bodies. The Napoleonic university model, dominant in many countries around the world, has been one of centralised direct control by the state over the university. Within this tradition, research was defined as servicing different public sectors, and the university was seen as a legitimate arena of state intervention (Musselin 2001). Modern universities in mainland Europe are no different in terms of being subject to regulation and control. They are deeply integrated with the state and have been granted 'special status in terms of autonomy and academic freedom based on a "social compact" that evolved between higher education, the state and society' (Enders et al. 2013, p. 7). The rise of mass higher education in particular has meant that the universities play a pivotal role in developing the economy and society and are monitored closely in this regard. The rise of new managerialism across the public sector (Clarke \& Newman 1997) has led to a new type of 'regulatory autonomy' for universities; they are regulated through external surveillance even though they can exercise organisational control of their own operations (Enders et al. 2013).

While governments do actively regulate universities as institutions, especially since the later 1990s, the control that is exercised over universities in the late

${ }^{2}$ Throughout the paper, we use the term 'university' (or 'universities') to denote all types of higher education institutions.

${ }^{3}$ Humboldt enshrined the freedom to teach and to learn (Lehrfreiheit and Lernfreiheit) as guiding principles for a university when founding the University of Berlin, while Newman, in his enunciation of 'The Idea of a University', claimed that the university 'contemplates neither moral impression nor mechanical production' (Newman 1852, p. 125-126). 20th and 21st centuries is neither exclusively national nor democratic. Global capitalist and geo-political interests exercise considerable indirect control of higher education through multilateral agencies including the European Union (EU), the Organisation for Economic Cooperation and Development (OECD) and the World Bank (Dale 2005, Lingard \& Rawolle 2011). A perusal of multilateral reports reveals a growing political assumption that universities are the intellectual engine of a global economy rather than a global society (OECD 2003, 2013, European Council 2011, World Bank 2011). While control and regulation operate generally in the form of 'advice', policy documents, such as the 'Country Reports' of the OECD, are thinly disguised 'surveillance' procedures promulgating a new market instrumentalism in education under the guise of 'independent' expertise (Henry et al. 2001). The control is exercised as 'soft' power in higher education, but it is real power nonetheless (Lo 2011).

Also, as universities are increasingly defined and funded to be generators and purveyors of (marketrelevant) knowledge, they have become marketable entities in their own right. Governments across Europe have endorsed a market view of universities as exemplified in the Bologna Declaration in 1999 (www.magna-charta.org/resources/files/BOLOGNA _DECLARATION.pdf), where the focus was on 'increasing the international competitiveness of the European system of higher education'.

The commercialisation of higher education was endorsed in an even more direct manner in recent years. The Official Journal of the European Union reported in 2011 that there was a

[...] need to reform further the governance and financing structures of universities allowing for greater autonomy and accountability, so as to facilitate a more diversified revenue stream and more effective collaboration with the business world and to equip universities to participate in the knowledge triangle on a global scale (http://eur-lex.europa.eu/legal-content/EN/TXT/ PDF/?uri=OJ:C:2011:372:FULL\&from=en).

While countries vary in the degree to which they sell their higher education services internationally, with the UK and Australia being especially direct in their marketisation (Marginson 2007, Ball 2012), private higher education is big business: it was worth an estimated $\$ 400$ billion globally, and approximately $25 \%$ of all higher education students were in private colleges in the late 2000s (Nuthall 2008). Even when universities are publicly funded and regulated, there is a growing expectation that they will subvent their state income from the sale of educational services (Department of Education and Skills 2011). Not sur- 
prisingly, therefore, recent private higher education expansion is overwhelmingly in the private-for-profit higher education sector, especially in the USA, but also in countries as diverse as Brazil, Korea and Poland (Douglass 2012). When university autonomy is championed, as it is in Europe, it is a bounded autonomy subject to political accountability (Nokkala \& Bacevic 2014).

Yet, the history of universities shows that they have always been 'communities of scholars' that worked to defend their academic freedom (Hamlyn 1996, Henkel 2005). The University of Bologna, the oldest of the European universities, founded in 1088, established a constitutional provision that guaranteed 'to protect scholars travelling for the purpose of study from the intrusion of all political authorities' (www.unibo.it/en/university/who-we-are/our-history/ university-from-12th-to-20th-century) within 60 years of its foundation. The right to academic freedom and autonomy, originating in Bologna in the 11th century, was ratified as part of the Magna Charta Universitatum on 18 September 1988 by 388 rectors from Europe and beyond and has since been ratified by 776 universities in 81 countries (www.magna-charta. org/resources/files/the-magna-charta/english). The charter has become a major reference for the fundamental values and principles of the university, including academic freedom ${ }^{4}$.

Although principles of academic freedom have often been challenged by religious, political or military dictatorships (Altbach 2001), and breached in various ways, through threats to the life and livelihood of academics (http://scholarsatrisk.nyu.edu/), dismissal (Elrod 2008) or simply 'pushing' people out of positions (Warner 2015), protecting the rights of scholars to pursue research and teaching, outside the control of powerful interest groups, remains a defining claim of university teaching and research. Universities are expected to be watchdogs for the free interchange of ideas and are licensed accordingly to protect freedom of thought, including the freedom to dissent from prevailing orthodoxies (Docherty 2015).

\section{ACADEMIC AUTONOMY AND ACADEMIC FREEDOM: INSTITUTIONS, INDIVIDUALS AND DISCIPLINES}

The European Universities Association has equated academic freedom with institutional autonomy, measured in terms of organisational, financial, staffing and academic autonomy vis-à-vis the State, and has ranked European Universities accordingly (www.university- autonomy.eu). However, while the institutional autonomy of universities matters, it is not synonymous with academic freedom. Institutional autonomy does not secure academic freedom for academics within the university per se, not least because the university as a corporate entity, especially as represented by its managerial elite, may be more aligned with state or multilaterial agencies (such as the European Commission) than the academics who comprise its core body of workers (Taylor 2006, Dale 2007, Nokkala \& Bacevic 2014, Warner 2015). Senior academics can and do become co-opted into the elite governance structures of science and higher education, and, as such, are incorporated into the decision-making machinery of the State (Henkel 2005).

Thus, struggles over autonomy are not confined to the relations between universities and the State; they apply to relations between those who govern universities (both directly at the vice-chancellor or presidential level, and indirectly through research councils and other higher education extra-university bodies such as quality assurance and labour-market planning agencies) and academic staff, especially in a new managerial age where power is highly centralised. The higher education elite can and does limit academic freedom by under-resourcing subjects for teaching and research, disallowing particular disciplines and fields of scholarly engagement and/or sanctioning dissent (Henkel 2005, Elrod 2008, Lynch et al. 2010).

Academic freedom is most commonly understood to refer to the freedom of individual teachers and students to teach, study and pursue knowledge and research, without unreasonable interference, institutional control or public pressure. It is defined as involving the freedom for academics to inquire into any subject that evokes their intellectual interest, to present their findings to students and colleagues and

\footnotetext{
${ }^{4}$ Academic autonomy is defined as a fundamental principle of a university under the Magna Charta Universitatum agreed by European University Rectors in Bologna in 1988. The university is an autonomous institution at the heart of societies differently organised because of geography and historical heritage; it produces, examines, appraises and hands down culture by research and teaching. To meet the needs of the world around it, its research and teaching must be morally and intellectually independent of all political authority and economic power. Academic autonomy implies having academic freedom, including the freedom of teachers and students to teach, study, and pursue knowledge and research without unreasonable interference or restriction from law, institutional regulations or public pressure. Academic freedom is also defined in the Magna Charta as a fundamental principle of university.
} 
to publish scholarly work without control or censorship. For students, it includes the freedom to study subjects that engage them and to form their own conclusions which they can then express freely. The individualised character of academic freedom is enshrined in law in a number of jurisdictions; it has constitutional protection in South Africa, Germany and the Philippines, and it has legal standing in the Universities Act of 1997 (www.irishstatutebook.ie/ pdf/1997/en.act.1997.0024.pdf) in Ireland ${ }^{5}$.

An individualised understanding of academic freedom, while vital for freedom of speech, does pose challenges for those who want to exercise it, as it requires them to defend a position or perspective on their own, with all the isolation this entails (Elrod 2008). It also means that there is no protection for scholars as a group to claim the right to freely undertake research on subjects of collective interest. Because scholarly work is held in common ownership (in the sense that we build on the work of others; Merton 1973), it generally evolves over time into a collective field of knowledge as a subject or discipline. The freedom to work in these fields or disciplines is a freedom that is very important for the advancement of scholarship. Yet, there is a lack of protection for what Merton (1973) has termed this 'communism' of scholarship, that which is produced and owned in common with others, within an individualised concept of academic freedom.

The relatively low proportion of research funding allocated to social scientific or humanities subjects relative to that allocated to disciplines deemed to have market relevance is common to both Europe and the USA (Slaughter \& Cantwell 2012, Warner 2015). It is a very silent but effective attack on disciplinary academic freedom as dissent is removed through organisational strangulation over time. The closure of whole departments of sociology in the UK during the Thatcher administration and the closing down of Cultural Studies at Birmingham University is proof of how the academic freedom to pursue collective critical thinking in higher education has been marginalised

\footnotetext{
5 In the Irish Universities Act of 1997 (14 [2]), academic freedom is equated with individual academic freedom. A member of the academic staff of a university shall have the freedom, within the law, in his or her teaching, research and any other activities either in or outside the university, to question and test received wisdom, to put forward new ideas and to state controversial or unpopular opinions and shall not be disadvantaged, or subject to less favourable treatment by the university, for the exercise of that freedom (www.irishstatutebook.ie/eli/1997/act/24/enacted/ en/print, accessed 15th January 2015).
}

institutionally (Gray 2003, Rutherford 2005). Attacks on interdisciplinary programmes such as Women's Studies, Gender Studies and Ethnic and Racial Studies in the USA are also proof of how attacks on collective, disciplinary-based critical thinking can limit academic freedom by silencing research epistemologies and teaching pedagogies that are challenging the atomized liberal individualistic model of both the research subject and student (Weber 2008). While the USA may appear as an exception, in so far as there has been a type of 'McCarthyism' in operation there since 9/11 (Silberstein 2004), the lack of respect for new interdisciplinary scholarship in the gender field is not confined to the USA (Buikema \& van der Tuin 2014). In Ireland, Centres for Equality Studies, Disability Studies and critically-oriented Development Studies were either struggling or in danger of being closed by the late 2000s (Lynch et al. 2010). Women's Studies Centres across most Irish universities have generally been merged into mainstream disciplines (Departments, e.g. History in Trinity College Dublin, Politics and Sociology in the National University of Ireland in Galway) and have no intellectual home of their own. They have been reduced to 'programmes' rather than 'subjects' and are relatively invisible as independent intellectual spaces.

While university autonomy matters for individual academic freedom, it does not guarantee it, and individualised academic freedom does not guarantee disciplinary freedom for communities of scholars or subjects. The operation of academic freedom is complex and contested, and this becomes even more evident when examining issues such as ethics, external controls and freedom.

\section{ETHICS, ACADEMIC FREEDOM AND CONSTRAINT}

The privilege of academic freedom is granted to scholars on the assumption that they will be guided by an ethical imperative to pursue the advancement of knowledge, while recognising the contested character of what constitutes 'truth' or 'knowledge' in scientific terms (Harding 1991, 2006, Kuhn 1962).

The mores of science possess a methodologic rationale but they are binding, not only because they are procedurally efficient, but because they are believed right and good. They are moral as well as technical prescriptions (Merton 1973, p. 270).

To realise its purposes of advancing knowledge, Merton identified 'four sets of institutional imperatives' which should govern the operation of scientific 
and scholarly research: 'universalism, communism, disinterestedness and organized skepticism' (Merton 1973 , p. 270). He noted how the universalism of science rests on the fact that it only makes truth claims that are subject to 'pre-established impersonal criteria' of appraisal, 'consonant with observation and previously confirmed knowledge' (Merton 1973, p. 270). In establishing knowledge claims, particularistic (including political or military) interests cannot determine the merits of an argument or the validity or reliability of scientific evidence. The second feature of scientific and scholarly research is, he claims, its communism: scientific research is about producing knowledge that is held in common ownership. The findings of science are the product of collective work, built on the work of previous scholars. Academics depend on the cultural heritage of their forebears and their peers and thus cannot lay an exclusive or differential claim to what they produce: 'The humility of scientific genius is not simply culturally appropriate but results from the realization that scientific advance involves the collaboration of past and present generations' (Merton 1973, p. 275). Scientific and scholarly work is also characterised by its 'disinterestedness', its detachment from vested interests, whatsoever their origins, and its internal norms of 'organised skepticism', where all truth claims are subject to critique and investigation by other scholars, no matter how sacred they may appear or how powerful the proponents.

It is because the university is presumed to serve the public good, and to equate its own self-interest, in research and education terms, with the public interest, that it has been granted autonomy. While the public knows that knowledge and research conducted by profit-driven operations and/or by other powerful interests can and are often subject to political influence, it is assumed that this is not the norm in the university. The status and credibility of university scholarship stems in considerable part from its disinterestedness and detachment from the powerful (De la Fuente 2002, Lieberwitz 2004). Academics are granted the freedom from necessity, in order to think and to write (Bourdieu 1993), because it is assumed they serve public interests rather than sectional powerful interests (Lieberwitz 2005). It is for this reason that university teaching and research have been largely funded from the public purse in Europe (ECOFIN 2010). Even in pro-market countries such as the USA, between 70 and $80 \%$ of funding for university life sciences research is publicly sourced (ECOFIN 2010).

Yet, contemporary critics of science would claim that the universities, as collective entities, are no longer working according to the normative principles elucidated by Merton, especially in terms of their disinterestedness. They are increasingly beholden to funding from the corporate sectors, directly and indirectly, so their autonomy and disinterestedness (in the sense of serving and enhancing the commons) are in serious jeopardy:

...it is clear that graduates in the natural sciences increasingly can find employment only in corporate labs; mostly, they are working for defense contractors, for pharmaceutical companies, or in electronic or biotech industries. And the university science departments, which historically isolated themselves from commercial interests and now and then from national state interests, today can claim little such autonomy. Their values are commercial and national state values (Harding 2006, p. 8).

Moreover, universities are big business, and education and research are tradable commodities. In research terms, universities provide opportunities to develop patents and commercialise products as scientific discoveries are increasingly defined as private properties (particularly since the passing of the BayhDole Act in the USA in 1980). Scientific achievements are seen as opportunities for creating a competitive advantage rather than a means of serving the public good in a disinterested manner (Münch \& Schäfer 2013).

The sale of educational services is a major export for several countries: in Australia alone, they were valued at Aus $\$ 17.2$ billion in $2008-09$, or about $1.4 \%$ of the GDP (OECD 2013). In the UK, the export of education services by universities amounted to £23.4 billion (US $\$ 43$ billion) in 2007-08. In gross output terms, this was equal to the value of the 'printing and publishing industry, and considerably larger than the pharmaceuticals industry' (Marginson 2007, p. 8). 'If higher education were an industry, it would be one of the world's biggest and most dynamic' (Yelland 2013).

The paradox of autonomy in this case lies in the ways in which academic freedom has been framed as a struggle against state meddling (and this can mean being free from the intervention of public interest in academic production), while failing to take due account of the way universities have become complicit with interventions by the market. While it is true that in modern liberal democracies the state has functioned as a mechanism to defend capital from labour, and mass higher education has been used as a redistribution mechanism to quell conflict (Panitch \& Gindin 2012), the question remains open as to whether academics should be cushioned against just any demands from democratic governments. In contemporary socialist countries such as Venezuela, aca- 
demic autonomy has been used by conservative academics to resist government attempts to democratize public universities and make access to higher education universal, and knowledge, socially pertinent (Ivancheva 2013).

In contemporary liberal democracies, the way in which ethical responsibilities map onto academic freedom in an increasingly corporatized, politicallydetermined, academic environment is contentious. If academics can only study, research and teach subjects that are corporatively funded or politically approved, and can only educate those who work for or service the commercial sectors, how free are they?

Under the Irish Universities Act of 1997 (14 [2]), individual academic freedom is explicitly protected at the individual level (see quote in footnote ${ }^{\underline{5}}$ ).

However, individual freedom is exercised under institutional constraints. The exercise of administrative power in Irish universities is highly centralised in the president or provost under the 1997 Universities Act: the president is defined by law as the 'chief officer' and the 'accounting officer' of the university. What this means, in effect, is that heads of universities have the power to exercise control over academics should they chose to exercise it. While there are institutional constraints on CEO power through various bodies, including academic councils, governing authorities and such, the law assigns ultimate power to the chief officer, not to the body of academics or other staff.

Moreover, state funding to public universities (and all universities, and most other higher educational colleges in Ireland, are public) is increasingly conditional on meeting government targets and demands, both directly in terms of the types of student education prioritised, and indirectly in terms of grant aid for highly selective fields and market-led research (Department of Education and Skills 2011, Department of Jobs, Enterprise and Innovation 2011). Academics who have the 'freedom' to research new ideas or to introduce new subjects are increasingly confined to fields of scholarship that are supported by government, which, in turn, are strongly influenced by business interests, especially those in science and technology. The impact of commercial interests is reflected especially in the funding of research. None of the subjects in the Arts Humanities and Social Sciences were listed as priority funding areas in the Research Prioritisation report for Ireland in 2011. Not only are science and technology prioritised for research funding, but within these fields, very specific areas are targeted ${ }^{\mathbf{6}}$. There are targeted incentives within Science Foundation Ireland's funding system to develop strong links with industry in mak- ing research bids, particularly through the Spokes programme (www.sfi.ie/funding/funding-calls/opencalls/sfi-spokes-programme-2013.html).

The positioning of higher education as a net contributor to the economy rather than a public service was accelerated by the austerity plans imposed by the International Monetary Fund, European Central Bank (ECB) and European Commission after the financial crisis in Ireland in 2008, although the process was in train prior to this (Lynch 2006). Private bank debt was translated into sovereign debt under pressure from the ECB in particular ${ }^{7}$, the net effect of which was to greatly reduce funding to higher education for both students and staff. This led to a series of increases in student fees (which are the second highest in Europe next to the UK; European Commission 2014), declining grants for maintenance, especially for low-income students, a reduction in university staffing and the increased casualization of academic and other staff appointments under what was known as the Employment Control Framework ${ }^{\mathbf{8}}$. There has also been a significant increase in fixedterm and part-time contracts in recent years and a deteriorisation of working conditions (Walsh 2012, Gallagher 2013, Loxley et al. 2014). The deteriorating working conditions were documented by the Irish Federation of University Teachers in a submission to the Expert Group on Fixed-term and Part-time Lecturers in August 2014.

\section{ACADEMIC FREEDOM, TENURE AND CASUALIZATION}

Although tenure is interpreted differently across different countries, implying permanent and civil service status in many mainland European countries, being a public sector employee but not a civil servant in some (Ireland and the UK), and having long-term

\footnotetext{
$\underline{6}$ Fourteen research priority areas are listed by the Report of the National Research Prioritisation group; none of these refers to the arts, humanities or social sciences, and all are listed as being in the science, technology and innovation field and are deemed to be market relevant.

${ }^{7}$ Correspondence between the President of the European Central Bank (ECB) Jean Claude Trichet and the Irish Minister of Finance Brian Lenihan in 2010 was released in November 2014; it shows that Ireland was forced to accept a bail-out on ECB terms.

${ }^{8}$ This involved the Higher Education Authority, the government body regulating higher education, having direct control over the numbers of staff employed in each higher education college from 2011 to 2014. Limits were set to the numbers of staff who could be employed at different levels.
} 
employment rights in the USA and Canada, in all cases it is understood as granting job security of employment in some form to academics (Karran 2007).

Proponents of academic tenure, including UNESCO (1997, p. 32) have insisted that 'Tenure constitutes one of the major procedural safeguards of academic freedom'. It gives faculty members the autonomy to challenge students intellectually and to challenge academic and university orthodoxies (Nelson 2012). It allows academics the freedom from necessity in order to think innovatively and independently, to resist negative administrative sanction, to collectively shape institutional decisions, and to secure certain liberties for non-tenured staff (McPherson \& Schapiro 1999, De George 2003).

At an institutional level, tenure is a way of creating incentives for innovation and excellence, and contributing to the continuity of intellectual memory in the university and its academic community (CEW 2010, Nelson 2012). Moreover, tenure is necessary on pragmatic grounds: in a world that is highly competitive for knowledge expertise, it allows universities to retain excellent scholars who might leave academia without security (Nelson 2012). Tenure allows academics to have a long-term engagement with, and commitment to, the institution of research and teaching (Karran 2007, Kaplan 2010).

Despite the widespread recognition of the importance of tenure for academic freedom and engagement, tenured employment has been declining for 50 years in the USA (Finkelstein 2007, National Center for Education Statistics 2011): it was $75 \%$ in 1970, $56 \%$ in 1975 and has declined steadily since then to reach 30\% in 2007 (Kaplan 2010). Moreover, newly hired faculty members work under increasing pressures to fundraise for their research, and engage in teaching, supervision and administration on everlowering salaries and contractual insecurity (Honan \& Teferra 2001). In Germany, while the number of university students has increased dramatically in recent decades, as has the number of non-professorial (non-tenured) staff, the number of professorships (permanent tenured chairs) has stayed the same (Enders 2001). Most demand for new academic employees has been met by hiring temporary faculty, whose number has increased by over $45 \%$ from 2000 to 2012. Four-fifths of the research and two-thirds of the teaching at German universities are covered by non-professorial academic staff, most of whom are employed on fixed-term contracts (Wissenschaftsrat 2014). While the average age of first professorial appointment in Germany is 41 , new legislation has made it impossible for academics to be employed in temporary positions for more than 6 consecutive years (Jungblut 2014).

A number of European countries have introduced a tenure-track system on the American model, including Humboldt University in Berlin, the University of Twente in the Netherlands and the new Aalto University (combining 3 former universities) in Finland. The University of Helskinki and Tampere University of Technology in Finland are also planning to introduce a tenured system. This effectively removes the security of tenure that academics had as civil servants (Herbert \& Tienari 2013). In Austria, the University Act 2002 radically altered working conditions for academics: there is no tenure-track career, and contracts are temporary until the person reaches the level of full Professor. Professors are subject to ongoing assessment every 3 to 6 years to retain tenure. New member states in the eastern periphery of the EU have championed lower-paid, open-ended contracts early in the researchers' careers (ESF 2009) for the employment of academics. The disjunction between good pay, job security and mobility has made the pursuit of a research career increasingly difficult for a new generation of scholars (ESF 2009, Kaplan 2010). In all types of countries, having tenure (even on limited terms) has become the privilege of a minority; there is a class-related generational injustice in this process, as older (generally) and established academics retain security while new entrants face a work life of increasing precariousness.

The European Science Foundation (ESF) has shown how women are especially vulnerable to tenure insecurity. They have dropped out of academic careers in ever greater numbers, especially as the requirement of geographic mobility and job flexibility make it difficult for them to dedicate time to family building 'in the rush hour of life' (ESF 2009, p. 10-11). In the USA, research by the Center for the Education of Women (CEW 2010) shows major gender differences between tenured and non-tenured staff. Within a sample of 343 academics in all fields and across 12 universities, it found that $75 \%$ of non-tenured faculty were women in the humanities, $60 \%$ in the social sciences and $46 \%$ in the natural sciences (CEW 2010).

Although there are some who have argued for the abolition of tenure, on the grounds that it may reward academic lethargy and that it allows for the reproduction of faculty of a rather uniform line of scholarship and opinion (Kaplan 2010, Schaefer Riley 2012, Wetherbe 2012, 2013), it is widely accepted that without tenure, it is more difficult to exercise academic freedom. As Leik (1998) observed, the crum- 
bling of the tenure system in the 1990s has led to the decreased interdisciplinarity, increased instrumentalization of research for business purposes, and a visible loss of rights to speak up because of fear of economic reprisal.

\section{THE GEO-POLITICS OF ACADEMIC KNOWLEDGE}

Academics are not only isolated scholars working to the norms of scientific rigour, but they also function as collective agencies, operating under different governance regulations cross-nationally (Altbach 2001): they are organised professionals with sectional interests and conflicting sets of values and goals (Rhoades 1983). Moreover, they are constituent members of the cultural elite, serving and oftentimes subservient to other elites (Bourdieu 1988). Historical evidence would suggest that academics have operated as a 'professorial oligarchy' in different countries at different times, and have often only been held to account in terms of student access for example, under pressure from governments. In the USA, it was the Morrill Acts of 1862 and 1890 that 'advanced egalitarian interests, promoting the regeneration and expansion of a public sector in higher education (through the land-grant college) and using federal funding as a weapon to enforce compliance in the area of discrimination...' (Rhoades 1983, p. 303). The Civil Rights Act of 1964 and the Higher Education Act of 1965 further consolidated these early gains.

While some academics have been at the forefront of social movement to make universities more open and accountable to those who are without power or money and/or who have not had the benefit of higher education themselves, this could not be said of academics as a corporate body cross-nationally (Rhoades 1983). Elite universities and their professoriate have jealously guarded their privileges over many generations and across very different countries (Bourdieu \& Passeron 1979, Bourdieu 1996, Schuetze \& Slowey 2002, Reay et al. 2009). Universities have had a long tradition of servicing the interests of powerful groups: the work of Mignolo (1999, 2009) and Bird (2001) shows how European universities have played a key role in cultural and intellectual colonisation across a range of continents that is deeply racialized. The 'Geo-politics of knowledge goes hand in hand with geo-politics of knowing.... it is a racially marked body in a geo-historical marked space that feels the urge or get the call to speak,...' (Mignolo 2009, p. 2). Globally, successful academics are overwhelmingly white, Western and male (Harding 1991, 2006, Alatas 2003, Connell 2007a,b). They come to know the world from the vantage point of Western epistemology with the limitations that this entails, not least the assumption that premier knowledge begins in the West and is framed through Western scientific understanding.

Western imperial knowledge was cast in Western imperial languages and was theo-politically and egopolitically founded. Such foundation legitimizes the assumptions and claims that knowledge was beyond bodies and places and that Christian theology and secular philosophy and science were the limits of knowledge-making beyond and besides which all knowledge was lacking: folklore, myth, traditional knowledge, were invented to legitimize imperial epistemology..... social actors who happened to be white, inhabiting Europe/Western Christendom and speaking specific languages assumed that what was right for them in that place and which fulfilled their affects, emotions, fears and angers was indeed valid for the rest of the planet and, consequently, that they were the depositor, warrantor, creator and distributor of universal knowledge (Mignolo 2009, p. 18-19).

Mignolo's critique suggests that the decolonisation of knowledge on a global scale is a key dimension of academic freedom. We do not just need a paradigmatic shift within the received wisdom of established disciplines (however valuable this may be), but rather to reframing of core questions about the world because of the historical and epistemological limitations of Western paradigms. We need to challenge the doxa that universal truths and universally applicable theories are produced in the Western metropole of knowledge production, whereas the periphery can only voice its local truths and create knowledge to solve nationally-specific problematics (Lomnitz 2001, Frank \& Meyer 2007). Academic freedom is not only about the rights of individual academics, it is also about the rights of communities of knowers to be recognised and enabled to name their own world academically (Freire 1970, Lynch \& O'Neill 1994).

A further and related reason for rethinking the epistemological basis of our knowing is because knowing is not confined to reason only, as much of Western thinking assumes it to be (Nussbaum 2001). What we know about the world is learned emotionally. 'Emotions are not irrational pushes and pulls, they are ways of viewing the world. They reside in the core of one's being, the part of it with which one makes sense of the world' (Nussbaum 1995, p. 374). It is our feelings in the world, especially our feelings of compassion arising from our own neediness, that compel us to be ethical. Knowing without feeling can 
be value indifference and politically dangerous because: 'Intellect without emotions is, we might say, value-blind: it lacks the sense of the meaning and worth of persons that the judgements internal to emotions would have supplied' (Nussbaum 1995, p. 381). Yet, much of academic thinking brackets issues of emotions and values outside of academic understanding, even though emotions and values inhabit research and teaching by virtue of what we know, what we choose not to know, what we prioritise and what we trivialise.

A rethinking of academic freedom therefore means recognising the lack of freedom of others geopolitically. It means recognising the cultural biases of dominant Western intellectual traditions, and the limitations they impose on our understanding of the world outside the linguistic, philosophical and paradigmatic frameworks of Cartesian, Eurocentric/ Western thought (Lynch et al. 2007, Sayer 2011).

Not only is academic life, and freedom within it, influenced by the geopolitics of academic scholarship, it is also influenced by the more local and personal biographies of academics. Feminists have identified the ways in which the domain assumptions of male researchers led to the trivialisation of the feminine, both in theory and in research (Harding 1991, Smith 2012), while disability studies scholars have shown how mainstream researchers, across many disciplines, disregarded the research and political interests of disabled people (Oliver 1992). The interface between the biographies of academics and their research subjects is therefore not simple; academics cannot step outside their culture, their embodied selves, either cognitively or affectively. The bearer of the research paradigm impacts on the paradigm itself; this is a deeply internalised constraint on academic freedom. This also means that students who attend universities are not academically free to learn all-there-is-to-beknown, as those who teach them do not know what they are unable to know, due to the limits of their biography, their paradigms and their culture.

\section{DOXAS OF THE ACADEMY - GENDERED CARE-LESSNESS, THE NEGLECT OF VALUES AND RELATED MATTERS}

\section{Time, care, gender and the organisation of university life}

Academic life is based on the premise that one has much time, personally-controlled time and care-free time to think, to write and rewrite: one needs freedom from necessity in order to be a successful academic (Bourdieu 1993). To have mentally free time, and time to cover distances of space (and of culture, through learning other languages) requires disengagement from other consuming forms of labour, one of the most greedy of which is care labour. This means that substantive as opposed to merely formal academic freedom assumes a relatively care-free life. This is a deeply gendered assumption, because while there are some changes in the amount of care work that men do, primary care-giving is overwhelmingly undertaken by women in contemporary Europe (GálvezMuñoz et al. 2011). Academic women are no exception (Bailyn 2003, Probert 2005). As not all caring can be delegated without being transformed (Lynch et al. 2007), those who have non-transferable dependency demands on their time and energy either cannot publish widely, or they cannot publish as much as others. Moreover, the self-marketisation required of academics (because the self is synonymous with the product in the case of an academic) is contingent on being able to be mobile in time and space, and to be able to delegate essential care and work to others. To globalise one's point of view, one must have time to do the promotional work that internationalising one's work requires, not only writing and research time, but carefree travel time, networking time, conferencing time and general self-promotional time. It is not surprising therefore that those who are well known academically (or indeed in literature or the arts) are disproportionately people who are care-free, namely men. A 24/7 model of working does not grant parity of academic freedom to women (and men) who are primary caregivers, as they simply cannot avail of it. The finiteness of human energy does not allow for it, no matter how elasticated people try to be (Devine et al. 2011).

The new market-led academy (Slaughter \& Leslie 2001) imposes expectations of performativity that only a care-less worker can fully satisfy (Moreau et al. 2007). Primary care-givers, most of whom are women, like people whose skin is brown or black (Ahmed 2012), do not quite fit the 'shapes' required by higher education organisations (Barry et al. 2007). They are strangers invoking emotions of fear among normal community members (Ahmed 2004). Even if one does fit the shape, having the body and the class shape to feel 'at home' in academia, is very challenging given the institutionalised white, middleclass, male-controlled genealogy of academia (Adair et al. 2007, Ahmed 2012, O'Connor 2014), especially at senior levels within entrepreneurial universities (Blackmore \& Sawers 2015).

The experience of being estranged is real and 
embodied, but it is largely silenced in neoliberal academia because for one to admit to experiencing exhaustion, stress, overload, or not being able to work intensely, or publish more, is to admit to failure. Yet, experiencing insomnia, anxiety, shame, aggression, hurt, guilt and a sense of inadequacy are ubiquitous if rarely articulated in the academy itself (Gill 2009). A University and College Union's survey in the UK found that academics in 'higher education are working under high stress levels - considerably worse than national averages'; they also found that stress levels had increased from earlier surveys in 1998 and 2004 (Court \& Kinman 2008, p. 3). For those who are on temporary and part-time contracts, the experience is even more intense.

\section{Values}

Understanding the care-lessness of higher education also involves appreciating the failure to recognise how values are encoded in all forms of research and education. There is, for example, an assumption in social scientific analysis that social actors are interest-led, power-led but not evaluatively led (Sayer 2006, 2011). Consequently, limited intellectual space or time is devoted to analysing how inevitable interdependencies and vulnerabilities shape social actions, and frame evaluations, beyond issues of status, power and materiality.

What Sayer (2005) has termed 'lay normativity' is outside the realm of academic analysis. Yet, in everyday life, people are evaluative beings; they are aware of likes and dislikes, good and bad, right and wrong in all social actions and interactions (Sayer 2011). People judge social situations in terms of secular or other ethical norms. By virtue of vulnerability and the need for others, and the human capacity to do good or harm, people are evaluative beings. The neglect of what people value, and their way of valuing, has led to a poor scientific understanding of what matters to people (Sayer 2011), and how interdependencies and vulnerabilities impel people to exercise judgements: judgements that are deeply affectively driven (Lynch et al. 2009).

At the root of the problem lies the concept of the ideal citizen informing higher education and research emanating from classical liberal education: the focus is on the development of the autonomous rational actor encapsulated in the Cartesian dictum 'cogito ergo sum'. The student is educated (and is understood socio-educationally) as living in the public sphere as an economic, political and cultural actor.
She or he is not educated for a relational life as an interdependent, caring and solidaristic human being (Lynch et al. 2007). Moreover, contemporary education draws heavily on Bloom's (1956) taxonomy of cognitive objectives, emphasizing the development of logical mathematical intelligence and abstract reasoning (Gardner 1983). It has inherited from classical liberalism an indifference to the affective domain and an allegiance to the education of the rational autonomous subject (Noddings 1984, 2003).

The deep-rooted care-lessness at the heart of academic thinking about the person-to-be-educated, and in university organisation, demonstrates the limits of the current Western understanding of academic freedom, and the narrow frame of scientific understanding underpinning it. The failure to appreciate the emotionality, relationality and evaluative dimensions of being human limits academic freedom to know people in all their complexity.

Neoliberalism shares with the classical liberalism a humanist tradition that defines the person as an autonomous and rational being. As such, it carries through into the 21st century a deep educational and philosophical indifference to the dependencies and interdependencies that are endemic to the human condition (Kittay 1999, Nussbaum 2001, Noddings 2003). In line with classical economic views of education, neoliberalism also defines the person to be educated in economic terms, as 'Homo economicus' a labour market actor whose life and purposes are determined by their economic status. These twin sets of values are reinforced with a third set of educational purposes, namely the conceptualisation of the person-to-be-educated as a highly individualised, self-regarding and consuming economic actor. Competitive individualism is no longer seen as an amoral necessity, but rather as a desirable and necessary attribute for a constantly reinventing entrepreneur (Ball 2003, Peters 2005, Apple 2006). What neoliberalism has succeeded in doing, however, which classical liberalism did not do, is to subordinate and trivialise higher education that has no market value. In that regard, it threatens future scholarly work in public interest values and systems outside the market.

\section{CONCLUSION}

The history of universities shows that they have been both hierarchical and patriarchal (Bagilhole 1993, Morley 1999, Saunderson 2002, Reay 2004, O'Connor 2014). They were not models of enlightened organisational practices even prior to the 
emergence of the endorsement of neoliberal values. Moreover, tenured academics are drawn disproportionately from white middle class backgrounds, and are more likely to be men than women (Reay 2004, Bagilhole \& White 2011). While there have been critical voices in higher education, critical of its pedagogy and its exclusivity (Hooks 1984, Harding 1991, Giroux \& Giroux 2004, Peters 2005, Apple 2010, 2012), it is also true that they have been minority voices, often working against the tide even in the pre-neoliberal days.

While there has been some intergenerational social mobility over the last 50 years, it is not primarily a meritocratic phenomenon (Brown 2013). The social class and racial background of those who enter higher education has remained relatively stable for almost half a century, especially if one measures higher education intake into socially prestigious and occupationally valuable degree programmes (DuruBellat et al. 2008, Rumberger 2010, Sianou-Kyrgiou 2010, Tieben \& Wolbers 2010) or elite university intake. Prestigious universities have drawn their intake disproportionately from the upper classes of society: the more prestigious the university, the more socially selective the intake (Giroux \& Giroux 2004, Reay et al. 2009, Buisson-Fenet \& Draelants 2013). Merit, race and social class have been aligned in a way that is deeply questionable in educational and social justice terms (Gomberg 2007).

The generative site of injustice does not rest within education alone. Economic inequalities between classes feed into educational inequalities in the status of the credential obtained, and the social networks available, leading collectively to labour market differentials in pay and opportunities (Franzini \& Raitano 2013). The aspiring middle classes face social congestion rather than social mobility in the labour market, however, with increasing competition for a small number of secure, reasonably well-paid positions. While educational attainment matters, social networking also plays a significant role in determining labour market outcomes from higher education in a highly competitive labour market situation (Brown et al. 2011, 2013, Franzini \& Raitano 2013).

Universities have not been innocent bystanders in this process: they have been embedded with professional interests, servicing those interests well from a functional perspective, but often doing little to challenge the evident social closure practices within powerful professional groups. They have been party to forming the power and status of the professional classes of the state (Hanlon 2000). Thus, attributing responsibility for the corporatisation of universities entirely to remote capitalist interests filtrated by the State is to disregard the role that the universities themselves have played in this process.

While the dismissal of a US professor for the expression of politically sensitive ideas (Elrod 2008) or the 'pushing out' of high profile and critical academics in the UK (Warner 2015) and the emergence of the Scholars at Risk ${ }^{9}$ network show that there are serious threats to critical scholars in a number of countries, the numbers of tenured Western academics being removed, or pushed, from their posts in the latter part of the 20th or early 21st century due to their exercise of academic freedom is very small. Tenured academics have worked under considerable protection for many years (Altbach 2001, Tierney 2004, Tierney \& Lechuga 2010, Herbert \& Tienari 2013). Yet, this protection has not always propelled them to proactively secure the same academic freedom for newer and/or future scholars. The recent commercialisation of universities, and the emergence of academic capitalism (Slaughter \& Leslie 1997) provided opportunities for both individual and corporate advancement. With it, higher education became fractured vertically and horizontally along age, gender and racial lines.

The rise of academic capitalism, both at the corporate and individual level, did not happen by accident, nor was it simply imposed arbitrarily from the outside. The failure of academics as individuals and universities as corporate bodies to challenge the spread of market values and new managerialism in higher education, and, at times, their collaboration with these for personal and/or institutional career gains has, in itself, diminished academic freedom.

The State didn't send out the secret police to transform higher education into an entrepreneurial sector: we have done that all by ourselves by taking the ethic of managerialism as the everyday practice of institutional life (Stuart Hall, cited by Giroux \& Giroux 2004, p.45).

Academics have an interest in autonomy and freedom that is vital for the independence of their scholarly work; however, as professionals, they are also making claims to power and status that are no different to that of other professional groups (Johnson 1972, Rhoades 1983). It is the conflation of these 2 statuses that must be examined, as the freedom to be intellectually autonomous is not always aligned with the interests of the professionally autonomous. The protection of professional interests may well operate

\footnotetext{
${ }^{9}$ See the Mission Statement of Scholars at Risk (http://scholarsatrisk.nyu.edu/About-Us/Mission.php).
} 
to foreclose dissent or limit access to higher education in the interests of preserving disciplinary and/or occupational monopolies and oligarchies. While the declining power of academics to 'rule the university' is attributable both to the rise of neoliberal policies in higher education and, at times, related moves by governments to regulate the autonomy of those who control large amounts of public money in a mass higher education system (Enders et al. 2013), academics, qua professionals, may also be in part responsible for their own declining autonomy and declining status.

It is time for a renewed reflexivity, a time to challenge the doxa (the unspoken underlying assumptions) of our own trade (Bourdieu 1993). This means naming the racialized, gendered, care-less and classed hierarchies of universities and how these undermine freedom. It also means recognising the threat to academic freedom posed by the increasingly precarious working conditions of scholars in so many countries, and recognising how the freedom of collectives to form and advance new disciplines, especially disciplines that are not market led, is increasingly threatened in a commercialised era by complicity with marketisation in the universities. It requires academics to publicly name the ways in which organisational strangulation and lack of resourcing of teaching and research can kill academic ideals and undermine freedom, albeit silently, over time. Overall, academics need to challenge powerful vested interests in higher education (Bailey \& Freedman 2011), including those of their own profession. Only in following the principle of disinterestedness can they protect their own freedom.

\section{LITERATURE CITED}

Adair V, Brown P, Clark N, Perez-Cotrich R, Stanfield S (2007) Poverty and storytelling in higher education: telling 'the missing story of ourselves'. Storytelling Self Soc 3:135-155

Ahmed S (2004) Affective economies. Soc Text 22:117-139

Ahmed S (2012) On being included: racism and diversity in institutional life. Duke University Press, Durham, $\mathrm{NC}$

Alatas SF (2003) Academic dependency and the global division of labour in the social sciences. Curr Sociol 51: 599-613

Altbach P (2001) Academic freedom: international realities and challenges. High Educ 41:205-219

Apple MW (2006) Educating the 'right' way: markets, standards, God, and inequality. Routledge, New York, NY

Apple MW (2010) Global crises, social justice, and education. Routledge, New York, NY

Apple MW (2012) Education and power. Routledge, New York, NY
Bagilhole B (1993) Survivors in a male preserve: a study of British women academics' experiences and perceptions of discrimination in a UK university. High Educ 26: 431-447

Bagilhole B, White K (2011) Building a feminist research network. In: Bagilhole B, White K (eds) Gender, power and management: a cross-cultural analysis of higher education. Palgrave Macmillan, Basingstoke and New York, NY, p 1-20

Bailey M, Freedman D (2011) The assault on universities: a manifesto for resistance. Pluto Press, London

Bailyn L (2003) Academic careers and gender equity: lessons learned from MIT. Gend Work Organ 10:137-153

Ball SJ (2003) The teacher's soul and the terrors of performativity. J Educ Policy 18:215-228

Ball SJ (2012) Performativity, commodification and commitment: an I-spy guide to the neoliberal university. Br J Educ Stud 60:17-28

Barry J, Chandler J, Berg E (2007) Women's movements and new public management: higher education in Sweden and England. Public Adm 85:103-122

Bird E (2001) Disciplining the interdisciplinary: radicalism and the academic curriculum. Br J Sociol Educ 22: 463-478

Blackmore J, Sawers N (2015) Executive power and scaledup gender subtexts in Australian entrepreneurial universities. Gend Educ 27:320-337

Bloom BS (1956) Taxonomy of educational objectives: the classification of educational goals. Handbook I. Longmans, London

Bourdieu P (1988) Homo academicus. Stanford University Press, Stanford, CA

Bourdieu P (1993) Sociology in question. Sage, London

Bourdieu P (1996) The state nobility: elite schools in the field of power. Stanford University Press, Stanford, CA

Bourdieu P, Passeron JC (1979) The inheritors: French students and their relation to culture. University of Chicago Press, Chicago, IL

Brown P (2013) Education, opportunity and the prospect for social mobility. Br J Sociol Educ 34:678-700

Brown P, Lauder H, Ashton D (2011) The global auction: the broken promises of education, jobs and incomes. Oxford University Press, New York, NY

Brown P, Reay D, Vincent C (2013) Education and social mobility. Br J Sociol Educ 34:637-643

Buikema R, van der Tuin I (2014) Doing the document: gender studies at the corporatized university in Europe. Part 2: Answering the sixty-four-thousand-dollar question. Eur J Womens Stud 21:194-199

> Buisson-Fenet H, Draelants H (2013) School-linking processes: describing and explaining their role in the social closure of French elite education. High Educ 66:39-57

> Cantwell B (2013) Assessing the public university. Br J Sociol Educ 34:152-161

CEW (Center for the Education of Women) (2010) Contingent faculty in a tenure track world: a report. Available at http://cew.umich.edu/sites/default/files/SloanFinalReport5-10.pdf (accessed on 15 January 2015)

Clarke J, Newman J (1997) The managerial state: power, politics and ideology in the remaking of social welfare. Sage, London

Connell R (2007a) The northern theory of globalization. Sociol Theory 25:368-385

Connell R (2007b) Southern theory: the global dynamics of knowledge in social science. Polity Press, Cambridge 
Court S, Kinman G (2008) Tackling stress in higher education. University and College Union, London

Dale R (2005) Globalisation, knowledge economy and comparative education. Comp Educ 41:117-149

> Dale R (2007) Changing meanings of 'the Europe of knowledge' and 'modernizing the university', from Bologna to the 'New Lisbon'. Eur Educ 39:27-42

$>$ De George RT (2003) Ethics, academic freedom and academic tenure. J Acad Ethics 1:11-25

$>$ De la Fuente JR (2002) Academic freedom and social responsibility. High Educ Policy 15:337-339

Department of Education and Skills (2011) National strategy for higher education to 2030. Government Publications Office, Dublin. Available at www.hea.ie/sites/default/ files/national_strategy_for_higher_education_2030.pdf (accessed on 15 January 2015)

Department of Jobs, Enterprise and Innovation (2011) Report of the Research Prioritisation Steering Group. Forfás, Dublin. Available at www.djei.ie/publications/ science/2012/research_prioritisation.pdf (accessed on 15 January 2015)

> Devine D, Grummell B, Lynch K (2011) Crafting the elastic self? Gender and identities in senior appointments in Irish education. Gend Work Organ 18:631-649

Docherty T (2015) Universities at war. Sage, London

> Douglass JA (2012) The rise of the for-profit sector in US higher education and the Brazilian effect. Eur J Educ 47: 242-259

Duru-Bellat M, Kieffer A, Reimer D (2008) Patterns of social inequalities in access to higher education in France and Germany. Int J Comp Sociol 49:347-368

ECOFIN (2010) Efficiency and effectiveness of public expenditure on tertiary education in the EU. European Commission, Brussels. Available at http://ec.europa.eu/ economy_finance/publications/occasional_paper/2010/ pdf/ocp70_en.pdf (accessed on 15 January 2015)

Elrod J (2008) Critical inquiry: a tool for protecting the dissident professor's academic freedom. Calif Law Rev 96: $1-32$

Enders J (2001) A chair system in transition: appointments, promotions, and gate-keeping in German higher education. High Educ 41:3-25

Enders J, de Boer H, Weyer E (2013) Regulatory autonomy and performance: the reform of higher education revisited. High Educ 65:5-23

ESF (European Science Foundation) (2009) Research careers in Europe: landscape and horizons. A report by the ESF Member Organisation Forum on Research Careers. Available at www.esf.org/fileadmin/links/CEO/ ResearchCareers_60p\%20A4_13Jan.pdf (accessed on 15 January 2015)

European Commission (2014) National student fee and support systems in European higher education 20142015. Available at http://eacea.ec.europa.eu/education/ eurydice/documents/facts_and_figures/fees_support.pdf (accessed on 15 January 2015)

European Council (2011) Council conclusions on the modernisation of higher education. Available at www.consilium. europa.eu/uedocs/cms_Data/docs/pressdata/en/educ/ 126375.pdf (accessed on 15 January 2015)

Finkelstein M (2007) The 'new' look of academic careers in the United States. In: Kogan M, Teichler U (eds) Key challenges to the academic profession. UNESCO Forum on Higher Education and International Centre for Higher Education and Research, Kassel. Available at http://nbn- resolving.de/urn:nbn:de:hebis:34-2008051421502 (accessed on 15 January 2015)

Frank DJ, Meyer JW (2007) University expansion and the knowledge society. Theory Soc 36:287-311

Franzini M, Raitano M (2013) Economic inequality and its impact on intergenerational mobility. Inter Econ 6: 328-335

Freire P (1970) Pedagogy of the oppressed. Penguin, London

Gallagher M (2013) Academic armageddon: an Irish requiem for higher education. The Liffey Press, Dublin

Gálvez-Muñoz L, Rodríguez-Modroño P, DomínguezSerrano M (2011) Work and time use by gender: a new clustering of European welfare systems. Fem Econ 17: 125-157

Gardner H (1983) Frames of mind: the theory of multiple intelligences. Basic Books, New York, NY

Gill R (2009) Breaking the silence: the hidden injuries of neo-liberal academia. In: Flood R, Gill R (eds) Secrecy and silence in the research process: feminist reflections. Routledge, London, p 228-244

Giroux HA, Giroux SS (2004) Take back higher education: race, youth, and the crisis of democracy in the post-Civil Rights Era. Palgrave Macmillan, New York, NY

Gomberg P (2006) How to make opportunity equal: race and contributive justice. Blackwell Publishing, New York, NY

Gray A (2003) Cultural studies at Birmingham: the impossibility of critical pedagogy? Cult Stud 17:767-782

Hamlyn DW (1996) The concept of a university. Philosophy 71:201-218

Hanlon G (2000) Sacking the New Jerusalem? - The new right, social democracy and professional identities. Sociol Res Online 5:9-16

Harding SG (1991) Whose science? Whose knowledge? Thinking from women's lives. Cornell University Press, Ithaca, NY

Harding S (2006) Science and social inequality: feminist and postcolonial issues. University of Illinois Press, Urbana, IL

Hazelkorn E (2011) Rankings and the reshaping of higher education: the battle for world class excellence. Palgrave Macmillan, Basingstoke

- Henkel M (2005) Academic identity and autonomy in a changing policy environment. High Educ 49:155-176

Henry M, Lingard B, Rizvi F, Taylor S (2001) The OECD: globalisation and education policy. Pergamon, Amsterdam

Herbert A, Tienari J (2013) Transplanting tenure and the (re)construction of academic freedoms. Stud High Educ 38:157-173

> Honan JP, Teferra D (2001) The US academic profession: key policy challenges. High Educ 41:183-203

hooks B (1984) Feminist theory: from margin to center. South End Press, Cambridge, MA

Ivancheva M (2013) The Bolivarian University of Venezuela: a radical alternative in the global field of higher education? Learn Teach 6:3-25

Johnson TJ (1972) Professions and power. Macmillan, London

Jungblut J (2014) Towards more predictable career-paths for young researchers in Germany. Available at http:// uv-net.uio.no/wpmu/hedda/2014/07/21/towards-morepredictable-career-paths-for-young-researchers-in-ger many/ (accessed on 15 January 2015)

Kaplan K (2010) The changing face of tenure. Nature 468: 123-125 
Karran T (2007) Academic freedom in Europe: a preliminary comparative analysis. High Educ Policy 20:289-313

Kaviani R, Salehi N, Ibrahim AZB, Nor MRM, Hamid FAFA, Hamzah NH, Yusof A (2012) The significance of the Bayt Al-Hikma (House of Wisdom) in Early Abbasid Caliphate (132A.H-218A.H). Middle-East J Sci Res 11:1272-1277

Kittay E (1999) Love's labor: essays on women, equality and dependency. Routledge, New York, NY

Kuhn TS (1962) The structure of scientific revolutions. University of Chicago Press, Chicago, IL

Leik RK (1998) There's far more than tenure on the butcher block: a larger context for the recent crisis at the University of Minnesota. Sociol Perspect 41:747-755

Lieberwitz R (2004) The corporatization of academic research; Whose interests are served? Akron Law Review 38 (4) 759-770

Lieberwitz R (2005) Confronting the privatization and commercialization of academic research: an analysis of social implications at the local, national, and global levels. Indiana J Glob Leg Stud 12:109-152

Lingard B, Rawolle S (2011) New scalar politics: implications for education policy. Comp Educ 47:489-502

Lo WYW (2011) Soft power, university rankings and knowledge production: distinctions between hegemony and self determination in higher education. Comp Educ 47: 209-222

Lomnitz C (2001) Deep Mexico, silent Mexico: an anthropology of nationalism. University of Minnesota Press, Minneapolis, MN

Loxley A, Seery A, Walsh J (2014) Higher education in Ireland: practices, policies and possibilities. Palgrave Macmillan, Basingstoke

Lynch K (2006) Neo-liberalism and marketisation: the implications for higher education. Eur Educ Res J 5:1-17

- Lynch K (2014) New managerialism, neoliberalism and ranking. Ethics Sci Environ Polit 13:141-153

Lynch K, O'Neill C (1994) The colonisation of social class in education. Br J Sociol Educ 15:307-324

Lynch K, Cantillon S, Lyona M (2007) Breaking silence: educating for love, care and solidarity. Int Stud Sociol Educ 17:1-19

Lynch K, Baker J, Lyons M (2009) Affective equality: love, care, and injustice. Palgrave Macmillan, Basingstoke

Lynch K, Crean M, Moran M (2010) Equality and social justice: the university as a site of struggle. In: Apple MW, Ball SJ, Gandin LA (eds) The Routledge international handbook of the sociology of education. Routledge, New York, NY, p 296-305

Marginson S (2007) Global position and position taking: the case of Australia. J Stud Int Educ 11:5-32

McPherson M, Schapiro M (1999) Tenure issues in higher education. In: Devlin M, Meyerson J (eds) Forum futures: 1999 papers. Foundation for the Future of Higher Education. Available at https://net.educause.edu/ir/library/pdf/ ffp9904.pdf (accessed on 15 January 2015)

Merton RK (1973) The sociology of science: theoretical and empirical investigations. University of Chicago Press, Chicago, IL

Mignolo WD (1999) I am where I think: epistemology and the colonial difference. J Lat Am Cult Stud 8:235-245

Mignolo WD (2009) Epistemic disobedience, independent thought and decolonial freedom. Theory Cult Soc 26: 159-181

Moreau MP, Osgood J, Halsall A (2007) Making sense of the glass ceiling in schools: an exploration of women teachers' discourses. Gend Educ 19:237-253

Morley L (1999) Organising feminisms: the micropolitics of the academy. Macmillan, Basingstoke

Münch R, Schäfer LO (2013) Rankings, diversity and the power of renewal in science. A comparison between Germany, the UK and the US. European Journal of Education 49:60-76

Musselin C (2001) La longue marche des universités françaises. Presses universitaires de France, Paris

National Center for Education Statistics (2011) Employees in postsecondary institutions, fall 2009, and salaries of fulltime instructional staff, 2009-10. Available at http: //nces.ed.gov/pubs2011/2011150.pdf (accessed on 15 January 2015)

Nelson C (2012) Should tenure for college professors be abolished? No. Available at www.wsj.com/articles/SB 10001424052702303610504577418293114042070 (accessed 15 Jan 2015)

Newman JH (1852) The idea of a university: defined and illustrated. Available at www.newmanreader.org/works/ idea/ (accessed on 15 January 2015)

Nokkala T, Bacevic J (2014) University autonomy, agenda setting and the construction of agency: the case of the European University Association in the European Higher Education Area. Eur Educ Res J 13:699-714

Noddings N (1984) Caring: a feminine approach to ethics and moral education. University of California Press, Berkeley, CA

Noddings N (2003) Happiness and education. Cambridge University Press, Cambridge

Nussbaum MC (1995) Emotions and women's capabilities. In: Nussbaum MC, Glover J (eds) Women, culture, and development: a study of human capabilities. Clarendon Press, Oxford, p 360-394

Nussbaum MC (2001) Upheavals of thought: the intelligence of emotions. Cambridge University Press, Cambridge

Nuthall K (2008) Global massive growth in private tertiary sector. Available at www.universityworldnews.com/article.php? story $=20080522124026121$ (accessed 19 May 2015)

O'Connor P (2014) Management and gender in higher education. Manchester University Press, Manchester

OECD (2003) Science, technology and industry scoreboard. OECD, Paris

OECD (2013) The state of higher education 2013. OECD, Paris

Oliver M (1992) Changing the social relations of research production? Disabil Handicap Soc 7:101-114

Panitch L, Gindin S (2012) The making of global capitalism: the political economy of American empire. Verso, London and Brooklyn, NY

Peters MA (2005) The new prudentialism in education: actuarial rationality and the entrepreneurial self. Educ Theory 55:123-137

Probert B (2005) 'I just couldn't fit it in': gender and unequal outcomes in academic careers. Gend Work Organ 12: $50-72$

Reay D (2004) Cultural capitalists and academic habitus: classed and gendered labour in UK higher education. Womens Stud Int Forum 27:31-39

Reay D, Crozier G, Clayton J (2009) 'Strangers in paradise'? Working-class students in elite universities. Sociology 43:1103-1121 
Rhoades G (1983) Conflicting interests in higher education. Am J Educ 91:283-327

Rumberger RW (2010) Education and the reproduction of economic inequality in the United States: an empirical investigation. Econ Educ Rev 29:246-254

Rutherford J (2005) Cultural studies in the corporate university. Cult Stud 19:297-317

Saunderson W (2002) Women, academia and identity: constructions of equal opportunities in the 'new managerialism' - a case of 'lipstick on the gorilla'? High Educ Q 56: 376-406

Sayer RA (2005) The moral significance of class. Cambridge University Press, Cambridge

Sayer A (2006) Language and significance - or the importance of import: implications for critical discourse analysis. J Lang Polit 5:449-471

Sayer RA (2011) Why things matter to people: social science, values and ethical life. Cambridge University Press, Cambridge

Schaefer Riley N (2012) Should tenure for college professors be abolished? Yes. Available at www.wsj.com/articles/ SB10001424052702303610504577418293114042070 (accessed on 15 January 2015)

Schuetze H, Slowey M (2002) Participation and exclusion: a comparative analysis of non-traditional students and lifelong learners in higher education. High Educ 44:309-327

Sianou-Kyrgiou E (2010) Stratification in higher education, choice and social inequalities in Greece. High Educ Q 64: 22-40

Silberstein S (2004) War of words: language, politics and 9/11. Routledge, London

Slaughter S, Cantwell B (2012) Transatlantic moves to the market: the United States and the European Union. High Educ 63:583-606

Slaughter S, Leslie LL (1997) Academic capitalism: politics, policies, and the entrepreneurial university. Johns Hopkins University Press, Baltimore, MD

Slaughter S, Leslie LL (2001) Expanding and elaborating the concept of academic capitalism. Organization 8:154-161

Smith LT (2012) Decolonizing methodologies: research and indigenous peoples. Zed Books, London

Stothoff Badeau J, Hayes JR (1976) The genius of Arab civilization: source of Renaissance. Phaidon Press, Oxford

Taylor J (2006) 'Big is beautiful.' Organisational change in universities in the United Kingdom. New models of insti-

Editorial responsibility: Konstantinos Stergiou,

Thessaloniki, Greece tutional management and the changing role of academic staff. High Educ Eur 31:251-273

Tieben N, Wolbers M (2010) Success and failure in secondary education: socio economic background effects on secondary school outcome in the Netherlands, 19271998. Br J Sociol Educ 31:277-290

Tierney WG (2004) Academic freedom and tenure: between reality and fiction. J Higher Educ 75:161-177

Tierney WG, Lechuga VM (2010) The social significance of academic freedom. Cult Stud Crit Methodol 10:118-133

UNESCO (United Nations Educational, Scientific and Cultural Organization) (1997) Records of the General Conference. Available at http://unesdoc.unesco.org/images/ 0011/001102/110220E.pdf (accessed on 15 January 2015)

Walsh BJ (2012) Turning knowledge into money: Ireland's universities and free-market alchemy. Studies 101: 215-226

Warner M (2015) Learning my lesson. Lond Rev Books 37 : 8-14

Weber M (1946) Essays in sociology. Oxford University Press, New York, NY

Weber C (2008) Academic freedom and the assault on interdisciplinary programs: re-articulating the language of diversity. Women Lang 31:51-56

Wetherbe JC (2012) Why I have a big problem with academic tenure. Available at www.businessweek.com/articles/2012-12-28/why-i-have-a-big-problem-with-acade mic-tenure (accessed on 15 January 2015)

Wetherbe JC (2013) It's time for tenure to lose tenure. Available at https://hbr.org/2013/03/its-time-for-tenure-tolose-te/ (accessed on 15 January 2015)

Wissenschaftsrat (2014) Empfehlungen zu Karrierezielen und -wegen an Universitäten. Available at www.wissenschaftsrat.de/download/archiv/4009-14.pdf (accessed on 15 January 2015)

World Bank (2011) Putting higher education to work: skills and research for growth in East Asia. Available at http:// siteresources.worldbank.org/EASTASIAPACIFICEXT/ Resources/226300-1279680449418/7267211-1318449387306/ EAP_higher_education_fullreport.pdf (accessed on 15 January 2015)

Yelland R (2013) The globalization of higher education. Available at www.oecdobserver.org/news/fullstory.php/ aid/3731/The_globalisation_of_higher_education.html (accessed on 15 January 2015)

Submitted: January 29, 2015; Accepted: June 11, 2015

Proofs received from author(s): September 17, 2015 